\title{
The Effect of Authentic Versus Non-authentic Aural Materials on EFL Learners' Listening Comprehension
}

\author{
Seyyed Ahmad Mousavi \\ Abadan PayamNoor University, Iran \\ E-mail: mosaviahmad55@yahoo.com \\ Hasan Iravani \\ Tehran PayamNoor University, Iran \\ E-mail: iravanitefl@gmail.com
}

Received: October 15, 2011

Accepted: November 9, 2011

Published: March 1, 2012

doi:10.5539/ells.v2n1p21

URL: http://dx.doi.org/10.5539/ells.v2n1p21

\begin{abstract}
The question put forward in this study was to pinpoint the impact of the authentic versus non-authentic listening materials on the listening comprehension of Iranian EFL subjects. After random selection, 80 upper-intermediate students from among all language institutes in Khoramshahr and Abadan cities, in Khuzestan province, Iran, took part in this study. The participants participated in two experimental treatment groups. During one semester, they were instructed in listening to authentic radio-tapes and non-authentic listening materials taken from the assorted sources. The results revealed that the participants who were instructed on the basis of authentic radio-tapes had gained a higher degree of listening comprehension and proficiency than non-authentic groups. Given the results of this experiment, the tentative extrapolations could be that some of the assumptions about the futility of teaching authentic listening materials should be rigorously re-examined. That is, the use of aural authentic listening materials in EFL classrooms improves learners' listening comprehension, and has positive effects on EFL learners.
\end{abstract}

Keywords: Authentic/non-authentic aural materials, Listening comprehension, Radio-tapes

\section{Introduction}

In a language classroom, listening ability plays a momentous role in the development of other language skills. Listening can help students build vocabulary, develop language proficiency, and improve language usage (Barker, 1971). Dunkel (1986:99) asserts that "developing proficiency in listening comprehension is the key to achieving proficiency in speaking". Listening skills are also the basis for the development of all other skills; and they are the main channel through which students make initial contact with the target language and its culture (Curtain \& Pesola, 1988).

Despite the importance of listening practice in language instruction, English- Language classes in Iran still emphasize only reading and writing skills more than listening. This is especially the case of an English-as-a-foreign-language (EFL) situation in which the English language is taught as a subject at school and used only inside, but not outside, the classroom. The students therefore are not accustomed to hearing the language as it is produced by native speakers for native speakers. Consequently, they have great difficulty understanding English spoken to them when they come into contact with native speakers of the language. This difficulty exists at a lower rate when they communicate with non natives.

One possible way to alleviate the problem can be using native-like listening materials, i.e. using authentic materials. The most common definition for authentic materials is unaltered texts that are generated by native speakers and for native speakers (Bacon, 1992; Joiner, 1991; Joiner et al., 1989; Rings, 1986; Rogers \& Medley, 1988; Scarcella \& Oxford, 1992). Authentic materials are also defined as oral and written language materials used in daily situations by native speakers of the language (Rogers \& Medley, 1988:468). Although we hear of many Englishs and English as a native language (ENL) has changed to English as a lingua franca (ELF) which places its stress on intelligibility, not on RP, many students and teachers like to learn English as spoken by natives. Many students aim to study or work in countries speaking English as L1. Accordingly, some examples of authentic materials are newspapers, magazines, and radio or television advertisements. Comprehension of authentic material is facilitated by some characteristics of 
the spoken language such as pausing, repeating, rephrasing, and the use of clauses rather than sentences (Schmidt-Rinehart, 1994; Wing, 1986). Authentic texts are more redundant than most texts prepared for language learners; the redundancy of these texts gives the students more clues to comprehension (Bacon, 1989; Gilman \& Moody, 1984; Meyer, 1984; Schmidt-Rinehart, 1994).

An advantage of introducing authentic materials at an early stage of language learning is to help students become familiar with the target language (Field, 1998). The use of authentic materials in ESL teaching and learning appears to be worthwhile (Porter \& Roberts, 1981; Rings, 1986). If the goal of an ESL/EFL program is "to prepare our students to cope with English outside the classroom" (Hafernik \& Surguine, 1979:341), it is suggested that teachers try to avoid speech modification and/or simplification [italic is mine] and to provide students with the kind of language that they are likely to encounter in real-life situations (Bacon, 1989; Ur, 1984). In addition, it has been recommended that teachers use listening materials that consist of samples of natural language from different sources so that students have experience with varieties of topics, situations, and speakers (Nagle\& Sanders, 1986).

Regarding the above significance of incorporating authentic materials in our language learning program, there is a dire need to conduct an empirical study on this issue in Asian environments because virtually few studies have been reported in these settings (EFL contexts), specifically in Iran.

Hence, this study, by and large, examined how the use of aural authentic input as opposed to non-authentic one in an EFL classroom eases and/or impedes students' learning in English-language listening. The fundamental objective was to scrutinize the influences of the use of aural authentic listening materials (radio-tape) on listening ability in students of English as a foreign language, and how it affects the participants` listening comprehension.

\section{Review of Literature}

Empirical studies have confirmed positive results obtained by listeners who are given opportunities to interact with authentic oral texts (Porter \& Roberts, 1981). On the elementary-school level, Duquette et al, (1989) reported that children using authentic texts improved linguistically. Herron and Seay (1991) in their study conducted with intermediate-level students, found that students who listened to authentic radio tapes as a substitute for regular classroom activities demonstrated significantly greater listening comprehension than those students for whom the authentic radio program had not been a part of the semester's curriculum. Their research indicates that listening-comprehension skill improves with increased exposure to authentic speech.

According to Omaggio Hadley (1993) and Rogers and Medley (1988), if students are to develop a functional proficiency in the language and to use the language communicatively in the real world, they must begin to encounter the language of that world in the classroom. Also, learners need opportunities to practice using the language to cope with everyday situations they might encounter outside the classroom.

Authentic materials can be even used from the first week of the first semester; however, the materials must relate to learners' life experiences and contain appropriate features that enhance comprehension at this level (Rings, 1986; Vandergrift, 1997). Feyten (1991) asserts that learners can handle authentic, unedited discourse although their success in comprehending may range from very little to considerable. Meyer (1984) and Richards \& Renandya (1983) suggest providing students with essential background knowledge and simple tasks to perform while listening.

Hansen and Jensen (1994) contend that students from all proficiency levels should be exposed to natural speech as a regular part of their listening practice. According to Bacon (1989), less-proficient students can understand and benefit from authentic texts. Schmitt (2002: 206) points out that it is crucial to assist learners approach fully authentic tasks progressively, rather than trying to make tasks lifelike from the start. To determine what needs to be done to prepare students for real-world situations, Joiner et al, (1989) suggested that teachers examine current practices and materials used in language classes so that teachers can determine what students listen to, how much they listen, and how they listen. And also implementing authentic speech in classroom listening allows students to have "immediate and direct contact with input data which reflect genuine communication in the target language" (Breen, 1985: 63).

It can be concluded, from this section, that there is an increasing interest in implementing authentic materials in a language classroom so that the students have opportunities to hear and practice using the language they will encounter outside the classroom. Also, several research studies have shown students' improvement in language performance because of exposure to authentic language in the classroom.

\section{Method}

\subsection{Setting and Participants}

A sample of 80 ten-semester students all in upper-intermediate level of English proficiency (determined through the 
ECPE test of proficiency), took part in this investigation. They were selected from among all 107 upper-intermediate level subjects enrolled in language institutes in Khoramshahr and Abadan cities, Khuzestan province, Iran. Based on the results obtained from the ECPE (Examination for the Certificate of Proficiency in English), the participants were divided into 2 experimental groups: 40 for authentic treatment and 40 for non-authentic one. They were in the 16-20 age range.

\subsection{Instrumentation}

A two-part pretest was administered. This pretest included a part for authentic and a part for non-authentic listening materials (reliability was found through KR-21 formula). The authentic part was compiled by the researchers and it consisted of 15 around two- or three minute authentic radio-tapes taken from BBC or VOA. For non-authentic listening materials the participants were instructed with usual listening materials selected from the listening part of New American Interchange and similar English programs like Headway and American Streamline. The contents of the listening materials were tried to be social and non-technical. The listening materials were mostly in the form of mini-dialogues or mini-lectures. Each mini-dialogue or mini-lecture was followed by two or three listening comprehension questions. This test helped the researchers keep track of the learners' listening improvement.

The post-test in this study was another sample test of listening comprehension for non-authentic listening material and a similar (described in pre-test) version of authentic radio-tape listening materials to determine the efficacy of the non-authentic and authentic radio-based treatment on the listening comprehension of EFL learners. The post-test had nearly the same characteristics in time, number, and content of the listening comprehension task used in pre-test. Both tests (pre- and post-tests) were made up of 32 items and each took about 32 minutes (one minute for each item). Time (5 minutes) was also given to participants to check their answers and transfer them to the answer sheet at the end of the test.

\subsection{Procedure}

The study was conducted at the start of the term (each educational year in our English Institute is divided into four terms). The participants' level of language proficiency was determined by ECPE test administered to all 107 participants. According to the results of this ECPE test, our 80 learners were selected. This way, there were two experimental groups of upper-intermediate students. After putting them into two groups, they were given special listening tasks for the whole term that took twenty sessions ( 10 weeks, two sessions a week), plus 3 test sessions. All the authentic listening tasks were prepared and designed by the researchers. The listening tasks in this research were applied according to the framework introduced in McDonough and Shaw (2003).

Concerning the lesson plan or the sequence of class activities, the following route-map was made and implemented all through the course: 'Stage 1: Pre-listening activities, Stage 2: While-listening activities (the actual listening task), and Stage 3: Post-listening activities. The same was followed by McDonough and Shaw (2003).

\subsubsection{Data Analysis}

The participants' level of language proficiency was determined by ECPE test administered to all 107 participants. Those students whose scores fell between $+0.5 \mathrm{SD}$ above and - 0.5 SD below the mean were considered as upper-intermediate. According to the results of this ECPE test, our 80 learners were selected. The means of the participants` performance on the both tests (pre and posttests) were compared before after the treatment.

\section{Results}

In order to pinpoint the effect of authenticity of the listening materials (radio-tapes) on the subjects' listening comprehension, their performance in non-authentic tests was compared to that of authentic ones in the pre and posttest stages.

\subsection{Comparison in the Pre-test}

As the Table 1 shows (see table 1 at the end of the article), the participants performance on the pretest stage showed no significant difference between on the authentic and non athletic materials because the t-observed value, 1.043, at 0.05 level is lower than the critical t-value (2.000) proving that the effect of the task in question is low and not statistically significant.

\subsection{Comparison in the Post-test}

According to the result obtained from the posttest stage, the participants instructed with authentic listening materials showed more enhancement in their listening ability because the t-observed value (6.176) exceeded the value of t-critical at 0.05 level which indicated that the difference between the two means is statistically significant(see Table 2). 


\section{Discussion and Conclusions}

Since development in a second language starts immediately upon students' exposure to the target language, at the beginning, as shown in a comparison between the participants' performance in authentic and non-authentic listening tasks in the pre-test of the current study, the students may not understand what they heard because of their unfamiliarity with native accents, vocabulary items, and native speakers' normal speed of utterance. As stated above, through the intervention process, the students gradually developed their language comprehension as they had opportunities to experience language used by native speakers of the target language via extensive listening practices.

The obtained results in the pre-test for authentic materials might be attributed to some interfering factors. In our view, one of the probable causes could be the relationship between 'text structure (text organization) and content familiarity'. Two views that describe this relationship have come into vogue. The first view states that the familiarity of the structure of a text is useful to listeners or readers who find the content to be unfamiliar. In other words, listeners or readers of unfamiliar text, through their formal schemata, rely on the structure of a text in order to make sense of the text; however, the structure of a text is not useful for listeners or readers who are familiar with the content (Taylor and Beach, 1984; Roller, 1990). In contrast, the second view states that the familiarity with the structure of the text is beneficial for the comprehension of both unfamiliar and familiar text contents (McKeown et al, 1992). This is because, according to the content schema (background knowledge of the content area of the text) as how to understand a text, one should have knowledge of the content words (lexical items) and how information is presented in various texts (Ghadessy, 1985). However, as mentioned previously, the participants, before treatment, had less familiarity with the structure of such texts (authentic listening materials). Because of the oddity of such texts in their educational setting, it can be argued that the results of this study in the pre-test pertain to what was hypothesized in the second view above. Since non-authentic materials lack many linguistic and paralinguistic elements, they seem to be easier to process and understand.

The rationale for this prospect is that the participants might have failed to benefit from the facilitative role of text structure, formal schema, to comprehend their contents. This issue can be in some way supported in the light of the comparisons between the participants ' performance in the pre- and post-tests with authentic listening materials. The participants ' significant performance might be related to their greater acquaintance with the structure of such texts in the post-test. These tests contained authentic passages which were near in text difficulty and content to the previous ones. This point can be partially sustained taking into account the fact that an intervention containing authentic radio-tapes might have possibly made the participants more familiar with the organization of such texts.

Along the same line, we can also come up with another plausible justification to account for the effect of text structure on the basis of Widdowson's characterization of authentic language. In his contention, an authentic text is "a pragmatically plausible piece in the sense that it exemplifies a contextually appropriate use of English, but it does not exemplify much language precisely because the discourse that is a function of contextual engagement leaves only a partial textual trace" (1998:709). The readers cannot infer the semantic meaning from the text because they cannot engage pragmatically with it, so the communicative potential of the language is left unrealized (ibid: 710). Since authentic texts are mainly written for L1 readers, they probably do not contain some of the rhetorical structures like discourse markers. For L2 readers, these discoursal rules might be essential for accessing appropriate formal schemata to comprehension. The entire or the partial lack of these organizational patterns can be viewed as a derivative cause to account for the participants' non-significant performance in the pre-test of the present study.

Another possible reason can be sought in the relationship between text coherence and degree of comprehension. The majority of utterances in the authentic mini-dialogues and mini-lectures in the current study were speech acts which involve the use of language to achieve behavioral effects on the listeners. According to Levinson (1983), when utterances within a segment of discourse are semantically connected with their "co-text", or are mutually relevant, and when the sentences are organized into some sort of conventional pattern (e.g., if the intent is to narrate a story, the first sentence is the setting rather than the climax), they are said to be "coherent" (P.107). Clarifying notions such as "connectedness" and "mutual relevance" in daily human interaction, Givon (1990) presents a set of four semantic properties with which to measure the extent to which a segment of discourse is coherent: (1) referent continuity, (2) temporal continuity, (3) location continuity, and (4) action continuity. The more of these properties a series of clauses and sentences share, the more coherent the discourse is (pp. 826-827). Further consideration of these factors suggests that, regardless of their organization, not all types of discourse, such as narratives and expository texts, will be equally coherent for listeners. For instance, a well presented narrative would have propositions that take the perspective of a single protagonist (i.e. referent continuity), take place in a single place and time frame (i.e. temporal and location continuity), and that consist of a series of interrelated events (i.e. action continuity).

How did the authentic and non-authentic types of listening materials used in this experiment differ in the degree to 
which individual sentences and segments cohered with their co-text? The observation indicated that such coherence was more pervasive in the non-authentic listening materials in the study. The non-authentic listening materials utilized many more propositions involving larger thematic organizations than did the authentic materials. Therefore, the non-authentic materials consisted of sentences that enjoyed a greater degree of connectedness. This lack in connectedness, and consequently the less coherence of the authentic listening materials might have led to the participants` non-significant performance in the pre-test

To sum up, the findings of this study show that implementing authentic listening materials in the EFL classroom help increase the level of their listening comprehension in the post-test stage. The study also shows that comprehension in EFL students improves after their exposure to authentic materials in the classroom due to the treatment, apparently. It can be concluded that to better prepare students and enable them to react accurately to the spoken language outside the classroom, it is necessary that teachers provide their students with ample opportunities to listen to samples of natural or real language, i.e. authentic language, in the classroom. Of course, care should be taken not to confuse the findings. Non-authentic materials also benefit students to a considerable degree and the importance of real life stuff does not exclude that of non-authentic educational materials.

\section{Pedagogical Implications}

In accordance with the effectiveness of instructional materials in the long run, it is important to synthesize the outcomes of this study in the light of pedagogical implications. With awareness of interest in authentic materials, whether they are prepared by the teacher or when they are web-based; one can easily help enhance the students listening comprehension level. In teaching and testing the listening skill, educational syllabi as well as instructional materials prepared might be more successful if they are adequately selected from more authentic listening materials. Authentic materials include all delicate points of real language, the points which are mostly ignored in non authentic materials. Hesitations, pauses, shift of functions, fillers and the like are some of theses points.

As far as the results of this study could support, listening materials, authentic or non-authentic, would have no gender effect on the students listening comprehension if their content is not biased to a specific gender. Therefore, the compilers of the texts and context for the pedagogic listening materials and authenticated ones should not be very much concerned with gender differences unless an element of gender shock or sensitivity is included in the text.

A classroom implication for this is that authentic materials should be implemented in any foreign and secondlanguage classroom. We believe that the real and unmodified materials are more useful to prepare students to face real English interaction. Normal speed and tone paves the way for a better understanding of listening corpus when students face natural and real situations.

Another classroom implication for this is that both authentic audio-recorded and video-recorded materials should be provided in any language instruction. If students are limited to the use of non-authentic audio-tapes in listening-comprehension practice, they will miss, for example, the cultural aspects of interactions between native speakers and the nonverbal cues such as gestures and facial expressions that facilitate the comprehension (Allen, 1999; Flynn, 1998; Herron, 1994; Secules et al., 1992). Different tasks may be implemented when teachers deal with the two types of materials; more intensive tasks focusing on the form are better for non-authentic materials and real life tasks are better practiced in the latter type.

Research shows that students' high score on the TOEFL (Test of English as a Foreign Language), a standardized test used to measure the English-language proficiency of foreign students applying to universities in the United States, does not assure the students' comprehension of a lecture (Dunkel \& Davis, 1994; Mason, 1994). We mean that although they have passed TOEFL successfully, and they have high marks in it, they may fail to interact and communicate suitably when they are exposed to a real life English situation. When you listen to the audio materials in TOEFL, you assume that robots are talking together. A dialogue on a campus matter, for example, does not start and finish on campus related matters. People in real life communication move through different functions and life matters very smoothly. We believe that a part of this deficiency in communication comes from their inability to understand more authentic listening materials such as lectures, in campus real talks, everyday chatting, etc.

The listening skills of these students are still inferior to those native speakers of the language. To compensate, we can provide a course in developing academic skills prior to the students' entering academic settings or any other real life English context. That is to predetermine English language learning programs, classes and situations where the learners especially, beside the other skills, have the chance and opportunity to be exposed to and use authentic listening materials. 


\section{References}

Allen, L. Q. (1999). Functions of nonverbal communication in teaching and learning a foreign language. The French Review, 72, 469-479

Bacon, S. M. (1989). Listening for real in the foreign-language classroom. Foreign Language Annals, 22, 543-551. http://dx.doi.org/10.1111/j.1944-9720.1989.tb02781.x

Bacon, S. M. (1992). Phases of listening to authentic input in Spanish: A descriptive study. Foreign Language Annals, 25, 317-334. http://dx.doi.org/10.1111/j.1944-9720.1992.tb00552.x

Barker, L. L. (1971). Listening behavior. Englewood Cliffs, NJ: Prentice-Hall.

Curtain, H. A., \& Pesola, C. A. (1988). Language and children- making the match: Foreign language instruction in the elementary school. Reading, MA: Addison- Wesley.

Dunkel, P. (1986). Developing listening fluency in L2: Theoretical principles and pedagogical considerations. The Modern Language Journal, 70, 99-106. http://dx.doi.org/10.1111/j.1540-4781.1986.tb05250.x

Dunkel, P. A., \& Davis, J. N. (1994). The effects of rhetorical signaling cues on the recall of English lecture information by speakers of English as a native or second language. In J. Flowerdew (Ed.), Academic listening: Research perspectives. pp. 55-74

Duquette, G., Dunnett, S., \& Papalia, A. (1989). The effect of authentic materials in acquiring a second language. Canadian Modern Language Review, 43, 479-492

Feyten, C. M. (1991). The power of listening ability: an overlooked dimension in language acquisition. The Modern Language Journal, 75, 173-180. http://dx.doi.org/10.2307/328825

Field, J. (1998). Skills and strategies: Towards a new methodology for listening. ELT Journal, 52, 110-118. http://dx.doi.org/10.1093/elt/52.2.110

Flynn, K. F. (1998). Bring language to life! Using video in your ESL/EFL program. [Online] Available: http://www.eslmag.com/bringlanguagetolife.html (26 Feb. 1999).

Ghadessy, M. (1985). Comments on recent articles on schema theory, a reader reacts: word knowledge and world knowledge. TESOL Quarterly, 19, 375-382. http://dx.doi.org/10.2307/3586838

Gilman, R. A., \& Moody L. M. (1984). What practitioners say about listening: Research implications for the classroom. Foreign Language Annals, 17, 331-334. http://dx.doi.org/10.1111/j.1944-9720.1984.tb03236.x

Givon, T. (1990). Syntax: A functional-typological introduction. Volume II. Amsterdam: John Benjamins. xxv, 553 pages. (Volume 1: 1984, xx, 464 pages).

Hafernik, J. J., \& Surguine, H. (1979). Using radio commercials as supplementary materials in ESL listening classes. TESOL Quarterly, 13, 341-345. http://dx.doi.org/10.2307/3585881

Hansen, C., \& Jensen, C. (1994). Evaluating lecture comprehension. In J. Flowerdew (Ed.), Academic listening: Research perspectives (pp. 241-268).Cambridge : Cambridge University Press.

Herron, C. A., \& Seay I. (1991). The effect of authentic oral texts on student listening comprehension in the foreign language classroom. Foreign Language Annals, 24, 487-495. http://dx.doi.org/10.1111/j.1944-9720.1991.tb00495.x

Herron, C. (1994). An investigation of the effectiveness of using an advance organizer to introduce video in the foreign language classroom. The Modern Language Journal, 78, 190-198. http://dx.doi.org/10.1111/j.1540-4781.1994.tb02032.x

Joiner, E. (1991). Teaching listening: Ends and means. In J. E. Alatis (Ed.), Georgetown, University round table on languages and linguistics1991. Linguistics and language.

Joiner, E. G., P. B. Adkins, \& Eykyn, L. B. (1989). Skimming and scanning with Champs-Elysees: Using authentic materials to improve foreign language listening. The French Review, 62, 427-435

Levinson, S. (1983). Pragmatics. Cambridge, MA: Cambridge University Press.

McDonough, J., \& Shaw, C. (2003). Materials and Methods in ELT (2nd ed.). A teacher guide. Blackwell Publishing.

Mason, A. (1994). By dint of: Student and lecturer perceptions of lecture comprehension strategies in first-term graduate study. In J. Flowerdew (Ed.), Academic listening: Research perspectives (pp. 199-218). Cambridge: University Press.

McKeown, M. G., I. L. Beck, G. M. Sinatra, \& Loxterman J. A. (1992). The contribution of prior knowledge and 
coherent text to comprehension. Reading Research Quarterly, 27, 79-93. http://dx.doi.org/10.2307/747834

Meyer, R. (1984). "Listening to my children, and you shall hear ...". Foreign Language Annals, 17, 343-344. http://dx.doi.org/10.1111/j.1944-9720.1984.tb03239.x

Nagle, S. J., \& Sanders S. L. (1986). Comprehension theory and second language pedagogy. TESOL Quarterly, 20, 9-26. http://dx.doi.org/10.2307/3586386

Omaggio Hadley, A. C. (1993). Teaching language in context: proficiency-oriented instruction (2nd ed.). Boston, MA: Heinle \& Heinle.

Porter, D., \& Roberts, J. (1981). Authentic listening activities. ELT Journal, 36, 37-47. http://dx.doi.org/10.1093/elt/36.1.37

Richards, J. C., \& Renandya, W. A. (2002). Methodology in language teaching: An anthology of current practice. Cambridge: Cambridge University Press. http://dx.doi.org/10.1017/CBO9780511667190

Rings, L. (1986). Authentic language and authentic conversational texts. Foreign Language Annals, 19, 203-208. http://dx.doi.org/10.1111/j.1944-9720.1986.tb02835.x

Rogers, C. V., \& Medley, F. W. (1988). Language with a purpose: using authentic materials in the foreign language classroom. Foreign Language Annals, 21, 467-478. http://dx.doi.org/10.1111/j.1944-9720.1988.tb01098.x

Roller, C. M. (1990). The interaction between knowledge and structure variables in the processing of expository text. Reading Research Quarterly, 21, 79-89. http://dx.doi.org/10.2307/747595

Scarella, R. C., \& Oxford, R. L. (1992). The tapestry of language learning: The individual in the communicative classroom. Boston, MA: Heinle \& Heinle.

Schmitt, N. (2002). An introduction to applied linguistics. Oxford: Oxford.

Schmidt-Rinehart, B. C. (1994). The effects of topic familiarity on second language listening comprehension. The Modern Language Journal, 78, 179- 189. http://dx.doi.org/10.1111/j.1540-4781.1994.tb02030.x

Secules, T., Herron, C., \& Tomasello, M. (1992). The effect of video context on foreign language learning. The Modern Language Journal, 76, 480-490. http://dx.doi.org/10.1111/j.1540-4781.1992.tb05396.x

Taylor, B. M., \& Beach, R. W. (1984). The effects of text structure instruction on middle-grade students' reading comprehension and production of expository text. Reading Research Quarterly, 19, 134-146. http://dx.doi.org/10.2307/747358

Ur, P. (1984). Teaching listening comprehension. New York: Cambridge University Press.

Vandergrift, L. (1997). The comprehension strategies of second language (French) listeners: a descriptive study. Foreign Language Annals, 30, 387-409. http://dx.doi.org/10.1111/j.1944-9720.1997.tb02362.x

Widdowson, H. G. (1998). Context, community, and authentic language. TESOL Quarterly, 32, 705-716. http://dx.doi.org/10.2307/3588001

Wing, B. H. (Ed.) (1986). Listening, reading, writing: Analysis and application. Middlebury, VT: Northeast Conference on the Teaching of Foreign Language.

Table 1. Comparison in the pre-test

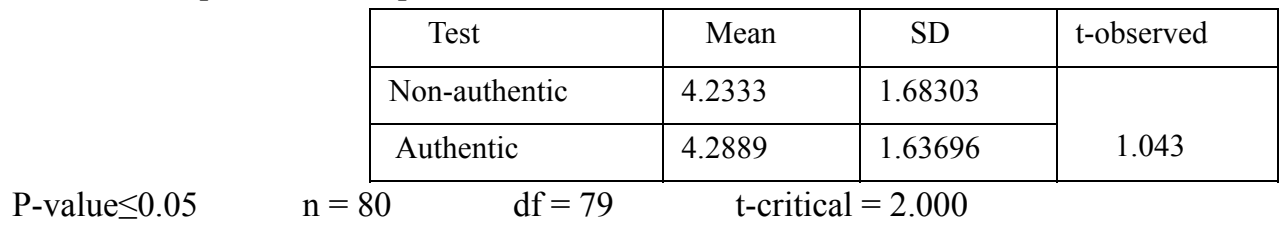

Table 2. Comparison in the post-test

\begin{tabular}{|c|c|c|c|}
\hline Test & Mean & SD & t-observed \\
\cline { 1 - 3 } Non- authentic & 4.2556 & 1.47306 & \multirow{2}{*}{6.176} \\
\cline { 1 - 3 } Authentic & 4.5556 & 1.41510 & \multirow{2}{*}{ Aut } \\
\hline
\end{tabular}

P-value $\leq 0.05$

$\mathrm{n}=80 \quad \mathrm{df}=79 \quad \mathrm{t}$-critical $=2.000$

